\title{
Economic Analysis of 4MW Distributed Photovoltaic Power Generation Project Based on PVsyst Software Simulation
}

\author{
WANG Hong ${ }^{1, a}$, WANG Zhijie ${ }^{2, b}$, FU Xiaolin ${ }^{3, c}$ \\ ${ }^{1}$ School of Economics \& Management, Tongji University, Shanghai, China; \\ ${ }^{2}$ Shanghai Dianji University, Shanghai, China; \\ ${ }^{3}$ College of Electrical Engineering, Shanghai Dianji University, Shanghai, China; \\ a wanghongpy@163.com, b wzjsdstu@163.com, c fuxiaolin12345@163.com
}

\begin{abstract}
We use PVsyst software to simulate and calculate the first year electricity generation of 4 MW distributed photovoltaic power generation project. In order to analyze and select the suitable power plant operation mode, the total generating capacity of photovoltaic power station in 25 years has been estimated by using component attenuation of 25 years. This research reports on the findings shown by PVsyst software that evaluates the economy aspects brought by two kinds of operation modes which are full grid access mode and spontaneous use of residual power grid access mode. The research content has reference value for the construction of roof distributed photovoltaic power station in China.
\end{abstract}

\section{Introduction}

This paper mainly uses the engineering design of PVsyst software to carry out simulation and calculation of the whole project, and draws the first year of power generation of the project, and then carries out economic analysis on the whole life cycle of the project.

\section{PVsyst software simulation}

\subsection{Geographic location and its solar resources}

The PVsyst software supports NASA and Meteonorm weather resource libraries. Due to the NASA meteorological database does not contain detailed hourly data, we chose to import hourly weather data from the city of Taizhou directly from the Meteonorm meteorological resource libraries.

\subsection{Solar module}

Researchers choose JKM270PP as the PV module with a power of $270 \mathrm{Wp}$ and the module has 60 solar cells.

\subsection{String type photovoltaic inverter}

The chosen PV inverter module is SG80KTL. The inverter is rated at $80 \mathrm{~kW}$.

\subsection{Photovoltaic array arrangement}

This project selects a fixed bracket solution. The project was selected to install the components at an inclination of $25^{\circ}$.

\subsection{PVsyst's simulation of the first year's power generation}

Through the above-mentioned parameter settings of the operating mode and arrangement, the simulation model of the project was established. The first-year hourly meteorological data of Meteonorm was used to simulate the first-year power generation of the system.

The PVsyst simulation shows the overall efficiency of the system is $84.28 \%$. It can be concluded that the total design of the system is reasonable.

\section{Project economic analysis}

\subsection{Project Investment Estimation}

The costs of the project includes many types of costs. According to the market survey, the various costs of the 4MW distributed photovoltaic power station project are considered in this paper.

It is estimated that the initial investment of the project is about 6.004 Yuan / Wp, the project design capacity is $4 \mathrm{MWp}$, and the total investment is 2,4016,000 Yuan.

\subsection{Analysis of national policy subsidies}

The 2018 photovoltaic power generation feed-in tariff is shown in Table 1. 
Tab.1 2018 PV power generation feed-in tariff list

\begin{tabular}{|c|c|c|c|c|c|}
\hline \multirow[b]{2}{*}{ Resource Area } & \multicolumn{2}{|c|}{ PV benchmark on-grid price $/ \mathrm{kWh}$} & \multicolumn{2}{|c|}{ Distributed power station subsidy $/ \mathrm{kWh}$} & \multirow[b]{2}{*}{ Remarks } \\
\hline & $\begin{array}{c}\text { Ordinary power } \\
\text { station }\end{array}$ & $\begin{array}{c}\text { Poverty } \\
\text { alleviation power } \\
\text { station } \\
\end{array}$ & Ordinary project & $\begin{array}{c}\text { Poverty } \\
\text { alleviation } \\
\text { project } \\
\end{array}$ & \\
\hline $\begin{array}{c}\text { Class I resource } \\
\text { area }\end{array}$ & 0.55 & 0.65 & \multirow{3}{*}{0.37} & \multirow{3}{*}{0.42} & \multirow{3}{*}{ Tax included price } \\
\hline $\begin{array}{c}\text { Class II } \\
\text { resource area }\end{array}$ & 0.65 & 0.75 & & & \\
\hline $\begin{array}{c}\text { Class III } \\
\text { resource area }\end{array}$ & 0.75 & 0.85 & & & \\
\hline
\end{tabular}

\subsection{Calculation of power generation during the life cycle of the project}

In practice, the efficiency of photovoltaic modules is declining every year, which means that the amount of electricity on the grid per year will decrease over time. Therefore, the attenuation of polycrystalline silicon solar modules must be considered when calculating the power of the power station. Table 2 is a table of attenuation parameters for polycrystalline silicon solar cell modules.

Tab.2 Attenuation parameter table of polycrystalline silicon solar cell module

\begin{tabular}{cccc}
\hline Years of installation & Power attenuation rate & Years of installation & Power attenuation rate \\
\hline First year power decay rate & $1 \%$ & 10 th year power decay rate & $8 \%$ \\
5th year power decay rate & $4 \%$ & 25 th year power decay rate & $20 \%$ \\
\hline
\end{tabular}

According to the above attenuation parameters,

Because the power plant is guaranteed to have a decay rate of less than $20 \%$ after 25 years of operation, the annual component attenuation rate is estimated to be $0.8 \%$.

From the graph, you can intuitively understand the numerical trend of the annual power generation of the entire power plant and the attenuation rate of the components. The component's 25 -year time decays to $80 \%$ of the factory's time. Therefore, the annual power generation of the power station is gradually attenuated from the initial year's $4539000 \mathrm{kWh}$ power generation to the $3,654,584 \mathrm{kWh}$ power generation in the 25 th year.

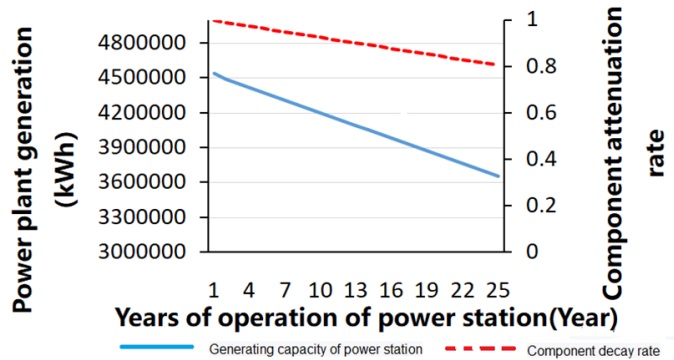

Fig.1 Attenuation curve of on-grid electricity during the life cycle of the power station

\subsection{Project Benefit Analysis}

\subsubsection{Full-emission operation mode}

The project is located in Taizhou City, Jiangsu Province, belonging to the Class III resource area. According to the latest on-grid tariffs set by the state for the photovoltaic industry in 2018, the photovoltaic power station uses its full-line operation mode to operate its Internet benchmark price of 0.75 yuan $/ \mathrm{kWh}$. The total revenue of the power station is calculated according to the following formula:

$$
\begin{aligned}
& W=P_{\text {solar energy }} \times T_{\text {Photovolta ic price }}(1) \\
& P_{\text {solar energy }} \quad \text { is } \quad \mathrm{PV} \text { power generation, }
\end{aligned}
$$

$T_{\text {Photovoltaic price }}$ is PV power station feed-in tariff. Among them, the electricity price of photovoltaic power station on-grid is divided into the following two parts: 0.75 Yuan $/ \mathrm{kWh}=0.391$ Yuan $/ \mathrm{kWh}$ (local price) +0.359 Yuan $/ \mathrm{kWh}$ (subsidies) (2)

Combined with the power generation of the power station within 25 years of the life cycle and the national electricity price policy for the PV power station, the revenue of the project using the full-emission method for 25 years can be calculated. The project financial evaluation data is shown in Table 3. 
Tab.3 Project financial evaluation data of full-emission operation mode

\begin{tabular}{ccc}
\hline Number & Project name(unit) & Value \\
\hline 1 & installed capacity (MW) & 4 \\
2 & Design life(year) & 25 \\
3 & first year power generation (kWh) & 4539000 \\
4 & years average power generation (kWh) & 4088792 \\
5 & Total investment of the project (yuan) & 24016000 \\
6 & Project 25-year total income (yuan) & 76676850 \\
7 & Average annual income (yuan) & 3067074 \\
8 & Payback period (year) & 7.83 \\
\hline
\end{tabular}

\subsubsection{Spontaneous use of residual power grid access mode}

According to the national electricity price regulations for photovoltaic projects, the comprehensive income formula of distributed photovoltaic power plants with self-sufficiency and surplus electricity on-grid operation is as follows:

$$
W_{\text {year }}=W_{\text {subsidies }}+W_{\text {self-use }}+W_{\text {grid-connected }} \text { (3) }
$$

Tab.4 Financial evaluation data of spontaneous use of residual electricity on-grid operation mode

\begin{tabular}{ccc}
\hline Self-use ratio & Project name (unit) & Value \\
\hline & Total project investment (Yuan) & 24016000 \\
\hline \multirow{3}{*}{ Self-use ratio 30\% } & Project 25-year total income (Yuan) & 78598804.19 \\
& Average annual income (Yuan) & 3143952.168 \\
& Payback period (year) & 7.64 \\
\hline \multirow{2}{*}{ Self-use ratio 50\% } & Project 25-year total income (Yuan) & 83726951.92 \\
& Average annual income (Yuan) & 3349078.077 \\
\hline \multirow{2}{*}{ Self-use ratio 70\% } & Payback period (year) & 7.17 \\
\hline & Project 25-year total income (Yuan) & 88855099.65 \\
& Average annual income (Yuan) & 3554203.986 \\
\hline
\end{tabular}

The project is calculated according to the 25-year operation cycle. Taking the self-use ratio in 30\%, 50\% and $70 \%$ as examples, the total income in the three cases was 78598804.19 Yuan, 83726951.92 Yuan, and 88855099.65 Yuan respectively. The investment recovery years were 7.64 years, 7.17 years, and 6.76 years, which met the relevant economic indicators.

\subsection{Comparison of the operation modes of the two power plants}

After the above discussion and analysis, we have already learned the respective revenue status of the distributed photovoltaic power plants under two different operating modes. As it is shown in Figure 2.

$$
\begin{aligned}
& W_{\text {subsidies }}=W_{\text {solar energy subsidies }} \times P_{\text {year }} \text { (4) } \\
& W_{\text {self-use }}=P_{\text {self-use }} \times T_{\text {price }(5)} \\
& W_{\text {grid-connected }}=P_{\text {grid-connected }} \times T_{\text {price }(6)}
\end{aligned}
$$

The financial evaluation data of the project is shown in Table 4.

\section{(n)}


developed through PVsyst software. The simulation aims to carry out reliable references which help us analyze and select the suitable power plant operation mode. The differences between full grid access mode and spontaneous use of residual power grid access mode have been compared by us. It can be concluded that the advantage of a power station operating in full grid access mode can only be seen when the proportion of self-use electricity is less than $20 \%$ and its advantages are not obvious

\section{References}

1. Zhou J, Kim S, Zhang H,etal.Consensus-based distributed control for accurate reactive, harmonic and imbalance power sharing in microgrids[J].IEEE Trans. On Smart Grid, 2015:99.

2. Shi J, Wang L, Wang Y, et al. Generalized energy flow analysis considering electricity gas and heat subsystems in local-area energy systems integration[J]. Energies, 2017, 10(4).

3. Liu X, Mancarella P. Modelling, assessment and Sankey diagrams of integrated electricity-heat-gas networks in multi-vector district energy systems. Applied Energy, 2016, 167:336-352.

4. Jin Xiaolong, Mu Yunfei, JiaHongjie, et al. Optimal day-ahead scheduling of integrated urban energy systems[J]. Applied Energy,2016,180;1-13.

5. XueXiaodai, Mei Shengwei,LinQiyou,etal.Energy internet oriented non-supplementary fired compressed air energy storage and prospective of application[J].Power System Technology,2016,40(1);164-171. 